\title{
"God met ons": \\ Gelowig nagedink oor die Skrif
}

\author{
Johan Buitendag \\ Departement Dogmatiek en Christelike Etiek \\ Universiteit van Pretoria
}

\begin{abstract}
"God with us": Faithfully reflected on Scripture

The theme of the article is a revisiting of the understanding of Holy Scripture from a dogmatic viewpoint. It is the author's conviction that the point of departure for such an exposition is revelation, which, of course, has to be deconstructed. The epistemological dilemma is that although revelation has ontological priority, it is only noetically accessible. Therefore, it is evident that Scripture has to be regarded as testimony, which puts it on the same level as tradition, except for the accord of the faith community. The application of the thesis is dedicated to the reception of revelation. Scripture then, is the accorded sediment of the reciprocity of the speaking God and a responding people. The conclusion is that the Bible does not have an intrinsic principle, but that referential meaning is given to it by the faith community. This ectopic center can only be ascribed to the work of the Spirit. This creates space for a scientific theology where an extra-systemic understanding of reality corresponds with an intra-systemic coherence.
\end{abstract}

\section{INLEIDING}

Die een tema wat maar telkens weer in die teologie terugkom en waaroor daar nie uitgepraat kan word nie, is die verstaan van die Skrif. Dit wil selfs voorkom of daar die laaste paar dekades 'n oplewing hieroor in die teologie was. Die vierde Wêreldkonferensie van Faith and Order (1963) in Montreal het hierdie debat met sy tema van "Scripture, Tradition and Traditions", ook 'n belangrike impetus én koers gegee (World Council of Churches 1980). Toe die destydse Gereformeerde Kerke van Nederland se verslag oor die aard en gesag van die Bybel, "God met ons", verskyn het (GKN-Rapport 1981), het die aktualiteit van die problematiek die Protestantse kerke in Suid-Afrika meteens getref (Van Huyssteen \& Du Toit 1982:1). Ons kan ook net maar op Litnet gaan kyk om iets van hierdie rimpel-debatte onder ons mense waar te 
neem (vgl Mollet, Grundling \& Van Heerden 2004). En daarom sou ek veral die debat oor homoseksualiteit wou uitsonder as die een enkele saak wat Skrifverstaan as sodanig opnuut onder die vergrootglas geplaas het, plaaslik sowel as in die buiteland. In die meeste kerklike debatte oor homoseksualiteit blyk dit dat die weë juis op die punt van Skrifbeskouing uitmekaar gaan (kyk bv Rogers 2006).

Tog is hierdie gemelde gebeure nie bloot die aanleiding tot die aktualiteit van hierdie debat nie, maar dalk eerder die illustrasie daarvan. Die ná moderne werklikheidsverstaan het hom eenvoudig op die teologie begin wreek en die veilige vestings en uniforme skanse van weleer indringend onder die loep geplaas. Veral die eenduidigheid van die Skrif het sterk onder druk gekom en hernieude erkenning is aan die historiese kritiek van die verstaan van die Bybel gegee. Collins (2005:2-3) wys byvoorbeeld op die bekende artikel van Jacques Derrida ${ }^{1}$ waarin hy die verhaal van die Toring van Babel (Gn 11) gedekonstrueer het en die sogenaamde taalverwarring eerder as 'n "celebration of diversity" getakseer het. Die bedoeling is om die teologie van finale uitsprake te bevry en ruimte aan pluraliteit te gee. Dit het natuurlik ook direk saamgehang met onder andere Gadamer en Ricoeur se insigte dat ons per definisie nie sonder ons vooronderstellings na 'n teks kan gaan nie en dus maar bra agterdogtig oor die rol van die subjek in die verstaan van enige teks behoort te wees. McFague (1982:56) formuleer dit derhalwe raak wanneer sy saamvat, "no eye is naked".

Die bydrae wat Gerd Theissen in die aktualiteit van die onderwerp maak, verdien vermelding. Vanweë die toenemende sekularisasie én pluralisme van godsdienste in die ná moderne wêreld, is daar wat hom betref, 'n al hoe sterker behoefte aan nuwe vorme van godsdienstige uitdrukking. Dieselfde geld ook vir 'n publieke etiek. Daarom kan dit haas nie anders as dat godsdienste met mekaar in gesprek moet begin tree nie. Die Bybel bied volgens Theissen daardie noodsaaklike bydrae tot die verstaan van die werklikheid én van onsself en dit op sigself noodsaak 'n openbare dialoog. Die God van die Bybel is tog die God van alle mense. Dialoog met ander godsdienste begin immers reeds in die Bybel. Juis daarom is dit noodsaaklik dat 'n Skrifbeskouing gedekonstrueer moet word (Theissen 2007:142-146).

Benewens ook sekere verwikkelings by die Bybelwetenskappe (soos bv die ontdekkings by Qumran, Nag Hammadi en die Evangelie van Judas, asook die (re-)konstruksie van die $Q$-Evangelie wat die kwessie van die kanon weer opnuut op die tafel geplaas het), het ek tog die indruk dat 'n bepaalde verwikkeling in die Sistematiese Teologie ook tans 'n belangrike rol

\footnotetext{
${ }^{1}$ Jacques Derrida (1992), Des Tours de Babel, in Poststructuralism as Exegesis, edited by D Jobling \& S D Moore. Semeia 54, 3-34.
} 
in die aktualiteit van die vraag na die aard en die gesag van die Skrif speel. Die laaste klompie dekades is daar in die Dogmatiek 'n hernieude belangstelling in die verstaan en die implikasie van die leerstuk oor die Triniteit. Toenemend word besef dat haas geen teologiese locus los daarvan geïnterpreteer behoort te word nie. So is dit onder andere byvoorbeeld moontlik vir 'n teoloog soos Jenson om die grond van die problematiek oor die Skrif, terug te voer na die wese van God self wat in dialoog met God self is: Jesus Christus is die adres van God se immanente ontologiese dialoog (Jenson 1991:270-272). Hierdie dialoog in God met Christus maak nou die gesprek met ons moontlik en daarvan getuig die Bybel gevolglik ook. Christus is dus die spreke van God in die geskiedenis. Daarom kan die kerk as geloofsgemeenskap in die Christus-spreke, juis ook met God praat - 'n ontologiese volgorde wat egter nie gemis durf word nie (Jenson 1991:272). Andersins kom mens by die onhoudbare situasie uit waar die mens God, selfs teen sy wil in, kan ken en greep op kan uitoefen! In 'n sekere sin kan ons sê dat die bloudruk vir die kerk hier te vinde is. Die wisselwerking in God self (perichoresis) is God se immanente storie wat bepalend is vir sy verhaal van genade met ons. Die ewige verheerliking van die Vader deur die Seun, is in die geskiedenis voortgesit deur die opstanding van die Christus - 'n verhaal waaraan ons nou mag deel. En al is die ná moderne tyd wars aan meesternarratiewe, is hierdie 'n meta-narratief ${ }^{2}$ waarsonder die Christen steeds nie kan nie. In hierdie verhaal word ons verstaan van die hede, geskiedenis en toekoms immers gekonfigureer.

Die uitdaging vir die Sistematiese Teologie is nou om 'n verstaan van die Skrif te probeer aanbied wat die delikate verhouding tussen openbaring, teks, gemeenskap en gelowiges se resepsie daarvan profileer (Webster 2003:8). Dit is dus nie soseer 'n bepaalde tese wat nou in die onderhawige aanbod beredeneer word nie, as eerder 'n sistematies-teologiese eksposisie van 'n bepaalde abduktiewe ${ }^{3}$ verstaan van die Skrif binne 'n ná moderne tydsgewrig. Die gedagte van die basislyn is in elk geval duidelik die

\footnotetext{
${ }^{2}$ Ek verkies die woord meta-narratief, want in die gees van Lyotard is 'n meesternarratief ' $n$ valse aanspraak op universele, rasionele en wetenskaplike gronde - asof dit onafhanklik van enige mite of diskoers is (kyk Smith 2007:68).

${ }^{3}$ Schnabel (2008:3) beredeneer in sy artikel oor die Skrif die opsies van 'n deduktiewe en 'n induktiewe verstaan van die Skrif as Gods woord, maar kom ongelukkig nie by die heuristiese waarde van 'n abduktiewe benadering uit nie. Abduksie het besliste waarde vir die teologie. Die volgende werkbare verduideliking kan aangebied word: "The main problem of belief revision is that the new information may be inconsistent with the corpus of beliefs, while the result of the incorporation cannot be inconsistent. This process can be done by the use of abduction: once an explanation for the observation has been found, integrating it does not generate inconsistency. This use of abduction is not straightforward, as adding to other propositional formulae can only make inconsistencies worse. Instead, abduction is done at the level of the ordering of preference of the possible worlds." (Abductive reasoning. Wikipedia, The Free Encyclopedia. 25/07/2008, http://en.wikipedia.org/w/index.php?title=Abductive_reasoning\&oldid=227746710).
} 
veronderstelling dat die sentrum van die Skrif nie intern nie, maar ekstern is, dus buite sigself setel. Hierdie ektopiese referensie kan alleen binne 'n holistiese beskouing van die verhouding Skepper, skepsel en skepping verstaan word. Ek vind derhalwe Topping (2007) se doktrinêre en historiese reduksie van wat die Skrif is, problematies. Op spoor van Torrance (1997:137) gaan dit vir my nie bloot om God wat spreek of bloot om die mens wat hoor nie; ons begin dus nie by óf God óf by die mens nie, maar by die wisselwerking ("resiprositeit") van God se genadige betrokkenheid in ons werklikheid waarvandaan en waaruit daar met die omsigtigheid van geloof, koers beskeie gesoek word. Dit klop ook ongeveer met wat Theissen (2007:78-90) bedoel het met die kontoere van transendensie, kontingensie en resonansie as religieuse ervaring.

\section{TRANSENDENSIE EN KONTINGENSIE}

Dogmenhistories wil dit blyk dat daar algaande belangrike verskuiwings ook in die Protestantse teologie se nadenke oor die Skrif na vore gekom het. Die Rooms-Katolieke Kerk het die kerk die inhoud van die interne prolegomena gemaak, aangesien die verhouding tussen God en mens deur die kerk as die instituut van openbaring en heil gekonstitueer is. Die vier eienskappe van die kerk soos in die Nicaeno-Constantinopolitanum uitgedruk, te wete eenheid, heiligheid, algemeenheid en apostolisiteit, is gevolglik eksklusief in terme van die RKK self verstaan. Die Hervormers van die sestiende eeu het in reaksie hierop en direk hierteenoor, weer die Bybel tot 'n kenteoretiese uitgangspunt ontwikkel. Dit het egter ewe rasionalisties-apologeties as die KontraReformasie van die RKK ontwikkel. Soos die kerk, kry die Bybel hierdeur ook sý eienskappe ${ }^{4}$ om onfeilbaarheid te bewys: Goddelike gesag (auctoritas), genoegsaamheid (sufficientia), deursigtigheid (perspicuitas) en selfwerksaamheid (efficacia). Die apoteose van die kerk by die RKK vind nou sy ekwivalent in die apoteose van die Skrif by die Protestantse skolastiek. Die basis van die geloof is dan nie meer God se liefde in Christus nie, maar die onfeilbaarheid van die Skrif. Sola Scriptura is in effek dus losgemaak van die regverdigingsleer se "deur Christus alleen" en absoluut opgeneem. Op hierdie wyse het die Protestantse skolastiek sy eie "pous" ontwikkel, hierdie keer net van papier! Die "sola" (scriptura) word in effek dan met 'n "tota" (scriptura) vervang en die kanon word 'n monolitiese geheel in sigself sonder enige geskakeerdheid en boonop met 'n intrinsiek-gefikseerde, oftewel ontologiese, referensie. Gevolglik word die openbaring as prinsipieel afgehandel beskou en die kanon juridies en ook andersins, finaal geslote.

\footnotetext{
${ }^{4}$ Vir 'n uiteensetting van die eienskappe van die Skrif, kyk Weber (1972:296).
} 
Hans Küng (1991:51-54) wys daarop dat sowel die Rooms-Katolieke teologie as die teologie van die Hervorming, hierdie skolastiese stolling egter algaande probeer afskud het. Die begrip "inspirasie" is by albei hierdie tradisies al hoe minder meganies-letterlik verstaan en het sodoende die onfeilbaarheid van die Skrif grootliks begin kwalifiseer. Die Bybelskrywers is nie meer as bloot "hagiografiese instrumente" gesien nie, maar as outeurs in eie reg. Alhoewel sowel die kerk as die Bybel in die gemelde twee tradisies openbaring veronderstel het, is dit steeds so uitgelê dat dit in hierdie onderskeie groothede in opgegaan het.

Die begrip openbaring het by beide tradisies algaande die inhoud van 'n teologiese kenleer begin vorm. Karl Barth was die doyen onder die Protestantse teoloë wat die openbaring van God as die vertrekpunt van sy teologiese ontwerp gemaak het (vgl die sogenaamde "Zuerst zu sagenden Dingen"). Dit het vir hom ook direk saamgehang met die Triniteit (Barth 1961:29-49). Die begrip openbaring kry ons ongelukkig nie uit die moeilikheid nie. ${ }^{5}$ Westermann (1978:19) oordeel immers dat die Ou Testament hoegenaamd nie openbaring as objektiveerbare grootheid ken nie, maar slegs as 'n gebeure: God wat spreek (teofanie) en God wat handel (epifanie). Barr $(1977: 121)$ is dieselfde mening toegedaan en stel dat dit haas onmoontlik is om by die tradisie, ' $n$ bepaalde antesedent van openbaring aan te toon. Openbaring is volgens hom eerder 'n eskatologiese begrip wat gebeure terugwaarts interpreteer. Tradisie volg nie openbaring nie, maar omgekeerd, openbaring volg tradisie: "The scripture provides the frames of reference within which new events have meaning and make sense" (Barr 1977:122). Anders gesê, openbaring is nie die bron van kennis nie, maar die explicans van die geskiedenis. Geskiedenis (of ervaring) is dus wat roep om interpretasie, dus die explicandum. Daarom het Pannenberg (1975:65) dit reg as hy sê dat selfs die ervaring van die teenwoordigheid van die Heilige Gees, geen selfstandige belewenis van openbaring kan wees nie; niemand moet op so 'n ervaring van die Gees wag om God in Jesus te bely nie, maar andersom, dit is deur die Gees dat iemand Jesus se lewe en werk as die openbaring van God herken en erken (vgl I Kor 12:3).

Dit is van kardinale belang om te konstateer dat God nie iets ván God openbaar nie, maar alleen God self. God bied ons nie soos 'n segment uit 'n sirkel, iets van sy wese aan nie, maar wel soos 'n sektor wat tot in die middelpunt strek. "Wij kijken Hem in het hart”, verduidelik Berkhof (2007:110) hierdie beginsel. Openbaring is dus nooit 'n habitus, 'n stuk

\footnotetext{
${ }^{5}$ Richard Topping (2007) is egter minder krities en spreek bepaalde kritiek uit teen Barr, Ricoeur en Frei se verstaan van die verhouding van openbaring en Skrif omdat volgens hom, Goddelike betrokkenheid in die Skrif onderskeidelik by hierdie drie geïgnoreer, veralgemeen of verswyg word.
} 
"geopenbaardheid" nie, maar altyd God se persoonlike Sélfbekendmaking in vryheid (Barth 1961:29-33). Waarheid is dus van huis uit 'n Persoon. Die bedoeling van die Bybel se boodskap is gevolglik primêr die heil van die skepping van God en nie die oordrag van 'n koue stuk kennis nie. Ons kan immers nie moderne epistemologiese vraagstukke net so op die Bybel superponeer nie. Die vraag is dus nie bloot, "wat moet ek weet?" (om gered te word nie), maar veral "wat moet ek doen?" (Hand 16:30). Of anders gesê, Bybelse kennis veronderstel altyd 'n soteriologiese gerigtheid.

Tog is die woord "openbaring" self ook nie sonder sy probleme nie (kyk o a Barr 1994:195). Die semantiese velde van hierdie woord verskil aansienlik tussen Afrikaans en Engels. Die deïstiese werklikheidsverstaan van die Engelse filosofie het tradisioneel haas geen rol in die verwysingswêreld van die gereformeerde kerke in Suid-Afrika gespeel nie. Die veronderstelling dat kennis deur Goddelike ingrype aangebied word, is weer aan die Engelse verwysingsraamwerk vreemd. John Barton, 'n hoof-medewerker in die gesamentlike projek oor Skrifverstaan tussen die universiteite van Oxford en Bonn, stel ook pertinent dat die Engelse en Duitse sistematiese teoloë totaal verskillende uitgangspunte in die teologie het: die Anglo-Saksiese teoloë begin heel gemaklik met godsdiensfilosofiese vrae, terwyl die Duitse teoloë weer met groot sekerheid oor die openbaring van God kan praat (Sauter \& Barton 2000:53). Daarom was die uitdrukking Revelation and Story as tema vir hulle gesamentlike projek, tegelyk die wedersydse kwalifikasie van die begrippe as die roete om oor God se dade in die geskiedenis te praat (Sauter \& Barton 2000:1). In sy klassieke werk oor die Heilige Gees, trek Hendricus Berkhof (1977:98) dieselfde onderskeid tussen die kontinentale en AngloSaksiese verstaan van openbaring: "Church and theology are bound to seek such a presentation of God's revelation that its relevance for our human existence and realities may become clear ... Anglo-Saxon theology constantly puts this fact before us, as a confession as well as a theological program."

Dit is dalk sinvol om die GKN-Rapport (1981) se uitdrukking "God met ons", as substituut vir die term openbaring te oorweeg, wel dan met die gemelde Anglo-Saksiese aksent. Na aanleiding van Ricoeur (1994:86) wil ek die uitdrukking, "God met ons", dus so toepas dat die ethos en die cosmos, (die sfeer van die menslike handeling en die sfeer van die wêreld), mekaar ontmoet en interpreteer. Dit voorkom 'n pretensieuse spreke "van bo" en bied tegelyk ook 'n beskeie, dog eerlike soeke na die teenwoordigheid en wil van God in en vanuit hierdie lewe (wat ek met abduksie wil bereik). God kom in elk geval nie anders as middellik na ons toe nie. Openbaring as 'n kliniese loodregte inbreuk van bo af, word dus afgewys. Het Barth nie met sy absolute openbaringsbegrip maar eintlik sy persoonlike credo tot 'n indrukwekkende 
dogmatiese paradigma ontwikkel nie, vra Barr $(1994: 20,103,190)$ ? Of soos Veldsman (2007:1344) dit skerp stel: "You first have to belief in Barth, then in God. He thus fell prey to precisely that psychological subjectivism which he sought to escape."

Avery Dulles (2004:193-210) het bepaalde modelle van openbaring geprofileer wat die sistematisering van die verstaan van die begrip openbaring in die teologie dien. Nadat hy die modelle intensief geanaliseer het, verwys hy in sy toepassing onder andere ook op die implikasie wat hierdie modelle vir 'n korresponderende Skrifverstaan inhou. Hy onderskei vyf modelle van openbaring (wat ek telkens met toepaslike voorbeelde illustreer). Eerstens kan openbaring as dogma verstaan word. Hiermee word bedoel dat openbaring in sekere proposisies vasgelê is soos deur God self geïnspireer. Ondersteuners hiervan beskou die Bybel as 'n tydlose, onfeilbare en geïnspireerde weergawe van 'n aantal leerstellings. Die uitverkiesing geld ook as vooronderstelling om die Bybel aldus te bejeën. Slegs die uitverkorenes deel hierdie insig. Die reeds gemelde attribute van die Bybel geld hier pertinent. Die Skrif benodig ook geen eksterne gesag of outoriteit nie, maar beskik intrinsiek daaroor deurdat die Heilige Gees self getuig ("outopistie"). As illustrasie sou na Artikel 7 van die Nederlandse Geloofsbelydenis van 1561 verwys kon word:

Ons glo dat hierdie Heilige Skrif die wil van God volkome bevat en dat alles wat die mens vir sy saligheid moet glo, daarin voldoende geleer word ... En aangesien dit verbode is om iets by die Woord van God by te voeg of daarvan weg te laat, blyk dit duidelik dat die leer daarvan heeltemal volmaak en in alle opsigte volkome is ... verwerp daarom met ons hele hart alles wat nie met hierdie onfeilbare reël ooreenkom nie, soos die apostels ons leer ...

Tweedens kan openbaring as geskiedenis gesien word. Die oortuiging bestaan dan dat God Homself in die gebeure van die geskiedenis openbaar, in die besonder daardie groot verhale waarvan die Bybel getuig, soos die uittog uit Egipte, die terugkeer uit ballingskap en die opstanding van Christus. Die Bybel is die betroubare getuienis hiervan en is dus nie openbaring as sodanig nie. Die begrip heilsgeskiedenis het gevolglik tot stand gekom en die Bybelskrywers is betroubaar in soverre hulle hierdie groot dade van God verhaal. Ook vir hierdie model is die Skrif selfgenoegsaam, minstens wat die Protestantse perspektief betref. Daarom word ' $n$ kanon agter die kanon as ' $t$ ware veronderstel wat die koherensie verseker van die verskillende outeurs van die Bybel. As voorbeeld kan ons aan Pannenberg dink. Deur nou "universaal-histories" te dink, word die hermeneutiese afstand tussen toe en 
nou, nou en eendag deur die geloof in Jesus Christus oorkom. In die derde plek word openbaring as persoonlike ervaring van die genade van God beskou. Die objektiewe en onpersoonlike geloofswaarhede van die eerste model of die groot dade van God in die geskiedenis van die tweede model, bevredig die ondersteuners van hierdie model glad nie. Uiteraard is daar variasies, maar sommige proponente hiervan meen selfs dat die tussenganger-rol van Jesus nie hiervoor nodig is nie. Meditasie en kontemplasie is dus heeltemal toereikend om die wil van God te verneem. Tillich (1964:47-48) verwys in hierdie opsig met groot waardering na Schleiermacher met sy "absolute afhanklikheidsgevoel" as eksponent van hierdie model en oordeel dat hy die Bybel in die proses te veel gerelativeer het. Hy verkies eerder 'n metode van "korrelasie" wat eksistensiële vrae in 'n wisselwerking met teologiese antwoorde kan bring (Tillich 1964:68). Anders as die fundamentalisme wat met 'n uitgediende konteks werk, wil hierdie metode juis die hede verreken om sodoende die diepste besorgdheid ("ultimate concern") van die mens eksistensieel aan te spreek. Die norm vir die teologie is nie die Bybel nie, maar die "New Being", die mens Jesus wat Christus genoem word (Tillich 1964:56). In hierdie paradoks bestaan ook ons as nuwe mense. Vierdens is openbaring as dialektiese teenwoordigheid opgeneem. Hierdie model het veral na die Eerste Wêreldoorlog in Europa ontwikkel. Dit verwerp sowel die objektivisme van die eerste twee modelle as die subjektivisme van die derde model. God kan nie geken word deur objektiewe dogmas nie en ewemin deur die bemiddeling van die natuur of die geskiedenis. Daarom is ook enige innerlike mistiese ervaring onaanvaarbaar. God ontmoet die mens in vryheid deur sy Woord waarin God ook teenwoordig raak. Hierdie woord is altyd tegelyk openbaring én verhulling. Karl Barth (1961:31) oordeel dat die Bybel effektief net een woord spreek, Woord met 'n hoofletter, te wete Jesus Christus. Die Bybel getuig daarom ook van niks anders as juis hierdie Selfopenbaring van God nie. Die kanon is daarom net relatief geslote juis omdat dit oor hierdie referensiële karakter beskik. God openbaar God self as die Here en Verlosser, nie anders nie. En dit is die Drieenige God wat Ou en Nuwe Testament saambind in die begrip, die "Koning van Israel". Openbaring is vir Barth (1961:40) 'n teken, 'n sakrament van God en daarom altyd indirek. Die Bybel is dus ' $n$ "teken van ' $n$ teken", die profetiesapostoliese getuienis van die primêre teken, Jesus Christus (Barth 1961:74). En laastens kan ons openbaring sien as 'n nuwe werklikheidsverstaan. Kritiek teen die bogenoemde perspektiewe het gewissel van 'n outoritarisme tot 'n fideïsme. Voorstanders van hierdie model sien openbaring weer as in die verlengstuk van die bewussyn of ook wanneer mense die sekulêre geskiedenis as God se weg met die wêreld eien. God is dus geen voorwerp 
van ervaring nie, maar is die transendente dimensie betrokke in die skepping. Waar Tillich ervaring as 'n middel van openbaring beskou het, wil hierdie model verder gaan en ervaring inderdaad as bron vir die teologie erken. Schillebeeckx (1966:187) is van oortuiging dat die menslike ervaringswêreld aan 'n "meerdimensionaliteit" geken word en dat dit konstitutief vir die waarheid is. Hy kom tot hierdie insig deur ' $n$ sintese van die heilsgeskiedenis en die Thomisme te maak. Dit beteken dat God by gewone menslike kennis, 'n meerdere dimensie toevoeg om sodoende bonatuurlike waarhede te ontsluit. Daarom kan die vraag volgens Schillebeeckx, inderdaad ook gevra word of "theologia" nie eerder "oikonomia" moet heet nie. Elke deelwaarheid roep om in die geheel opgeneem te word; daarin word dit dan "eingeheimatet" (Schillebeeckx 1966:309). Die Prosesteologie het inderdaad hierdie sentiment ook uitgebou. John Cobb (1994:88) byvoorbeeld, sê ronduit dat die grense tussen tradisie en Bybel opgehef moet word. Alle fokus moet eerder op transformasie van die Christendom wees: "It is in the transformation that I find the effective presence of the living God. My deepest commitment is to this process of creative transformation rather than to any of its products" (Cobb 1994:91). Die Bybel is dan geen "mythical archetype" nie, maar wel ' $n$ "historical prototype" (Fiorenza 1984:14).

Maar is dit moontlik om hierdie modelle suiwer toe te pas? lemand soos Webster (2003:1-2, 5-10, 27) neem weliswaar openbaring as uitgangspunt in sy Skrifverstaan, maar kwalifiseer dit onmiddellik. Daarom wil hy die woord "Holy" altyd saam met die woord "Scripture" sê. Dit veronderstel enersyds die konteks van die kerk, andersyds die geloof in die Goddelike oorsprong daarvan. Dit waarborg ook dat die Heilige Skrif nie op sigself bestaan nie. ${ }^{6}$ Hierdie "geloofsbedding" met God as die Subjek, is onontbeerlik vir Skrifverstaan. Daarom is die siklus van openbaring - teks geloofsgemeenskap - gelowige resepsie deurgaans so belangrik. Om dit vervolgens te bereik, laat Webster hom met 'n kontinuum van "openbaring", "sanktifikasie" en "inspirasie" van die Heilige Skrif bedien. Die begrip heiligmaking funksioneer vir hom dus as 'n soort middelterm om juis die wil van God in die alledaagse lewe te manifesteer. Hierdeur meen hy om die uiterstes van sowel 'n supranaturalisme as 'n naturalisme te oorkom en die Woord van God midde-in hierdie wêreld te plaas (Webster 2003:21). Die Woord is inderdaad 'n skat in kleipotte (2 Kor 5:7).

Luther het eintlik verder as Webster gegaan in sy dekonstruksie van die term openbaring. Hy gebruik dit heel spaarsamig en probeer inderdaad "van onder" af oor ons verhouding met God te reflekteer. Openbaring is vir hom konsekwent in terme van die koms (en wederkoms) van Christus te

\footnotetext{
${ }^{6}$ 'n Fout wat ek juis meen Topping $(2007: 4,213)$ in sy verstaan van die "ontologie van die Skrif" maak.
} 
verstaan. Aan die kruis het God Homself egter sub contrario geopenbaar. Dit beteken dat die Deus absconditus in Christus tegelyk die Deus revelatus is. Wat nou volgens Luther vir die mens oorbly, is alleen maar die geloof (Ebeling 1977:272). Openbaring hou dus geensins elitistiese kennis by die gelowige in nie. Froelich gaan selfs so ver as om te sê dat by Luther, geloof die openbaring in die tegniese sin van die woord vervang het (Fretheim \& Froelich 1998:28-29). Dit klop, indien mens byvoorbeeld die volgende uitspraak van Luther (1999) oor Genesis 17:23 in oënskou neem waar hy geloof die kriterium vir alle onderskeiding maak: "All apparitions must be tested according to the norm of faith, and one must ask whether they are in harmony with faith, or indeed, as usually happens, conflict with the revealed Word."

Dit hang natuurlik saam met die feit dat Luther die eksistensiële pro me as die matrys vir sy teologie ontwikkel het. Ons ken God nie in terme van 'n wêreld-prinsipe wat die oorsaak van alles is en die genade gevolglik 'n ingebore eienskap van die mens is nie (Ebeling 1977:274-275). Nee, die gelowige is in 'n persoonlike relasie met God en daarin en daaruit lewe hy of sy. Die kruis van Christus vorm die locus theologicus waar hierdie ontmoeting realiseer. Kenteoreties kan ons dus aflei dat die Bybel ervaring interpreteer. So kan Luther (1999:11) byvoorbeeld aandui dat die gevoel van die afwesige God wat die dissipels daardie Vrydag met die kruisiging beleef het, alhoewel eg menslik, deur die openbaring in 'n ander perspektief geplaas is en aantoon dat God sowel verborge as teenwoordig is. Die Woord interpreteer dus ervaring en plaas dit in 'n nuwe raam. Juis daarom is die gelowige ook positief oor die toekoms. Dit gaan nie om eie insigte nie, maar om God se belofte. Daarom kon Luther ook God bly prys vir die seëninge in die alledaagse lewe. Die Vader word geprys omdat sy liefde in die Seun ontmoet word en wie se stem deur die werking van die Gees gehoor word. Nürnberger (2005:23) beklemtoon hierdie bemiddeling van God, te midde van die verborgenheid en die openbaring, in sy weergawe van Luther se teologie. Ons spekuleer nie oor God se grootheid, bestaan of liefde nie - ons ervaar God. Luther het alle kreatuur gevolglik as larwes of maskers van God beskou. Tog oorstyg God se immanensie enige vorm van 'n panteïsme (Steinmetz 2002:24).

\section{RESONANSIE EN WISSELWERKING}

Dit behoort duidelik te wees dat openbaring nooit los van geloof gemaak kan word nie. Trouens, die geloof is juis die wyse waardeur openbaring geëien word. Hierdie problematiek van die voorrang ten opsigte van openbaring en geloof, kan in terme van die verskil in ontiese en noëtiese vertrekpunte aangetoon word. Alhoewel die ontiese die noëtiese prinsipieel voorafgaan God wat die Skepper van alles is - word dit van die mens se kant af gesien, weer primêr noëties erken en is dit dan weer die vertrekpunt. Ons ken immers 'n saak altyd aan die effek daarvan. Dit is juis die punt wat Luther wil oorbring 
deur eksistensieel van onder af te glo en te dink. Dit is treffend om na sy Groot en Klein Kategismus in hierdie verband te luister wanneer hy die eerste artikel van die Apostoliese Geloofsbelydenis oor God die Skepper verduidelik: "Ich glaube, daß mich Gott geschaffen hat samt allen Kreaturen, mir Leib und Seele, Augen, Ohren und alle Glieder, Vernunft und alle Sinne gegeben hat und noch erhält; dazu Kleider und Schuh, Essen und Trinken, Haus und Hof, Weib und Kind, Acker, Vieh und alle Güter" (Luther 1983:41).

Luther kan nie anders as om vanuit sy persoonlike situasie oor God die Skepper te reflekteer nie. Hy is ook heel aards daarin: klere, skoene, kos, drank, ja, alles wat goed is kom van God af. Daarom is dit vir McGrath (2003:13) so belangrik om ook die aposterioriese aard van die teologie ${ }^{7}$ te beklemtoon. Dit gaan dus om 'n benadering waar daar 'n persoonlike betrokkenheid met die besondere plaasvind.

Pannenberg het dit reg as hy sê dat die Protestantse Skrifprinsipe in 'n krisis verkeer nie net vanweë die historiese kritiek nie, maar ook vanweë die hermeneutiek. ${ }^{8}$ Die Bybel se diversiteit en historisiteit is eenvoudig net te oorweldigend om geïgnoreer te word: "Die 'Sache' der Schrift, die Luther im Sinne hatte, nämlich Person und Geschichte Jesu, ist für unser historisches Bewußtsein nicht mehr in den Texten selbst zu finden, sondern muß hinter innen erschlossen werden" (Pannenberg 1979:15). Sowel die integriteit van die teks as die rol van die leser moet dus erken word. Die primum principium kan dus geen intrinsieke metafisiese kwaliteit in die Skrif self wees nie, maar is alleen God wat in sy genade na ons toe uitreik en aldus deur die gelowige beleef word. Dit is in hierdie aspek wat Webster (2003:95) juis ook die perspicuitas van die Skrif wil sien. Dit is geen ontologiese gegewe nie, maar 'n ontmoeting in die geloof. En dit moet so aanvaar word. Daarom is die behoorlike lees van die Bybelteks nie net 'n bloot tegniese vaardigheid wat aangeleer word nie, maar veral ook 'n gebeure wat relatief tot die gelowige groei (Bonhoeffer 1996:64). Deurdat Christus nou deur die Skrif aan die woord kom, realiseer sy teenwoordigheid en word dit God se Woord. Ebeling (1960:333, 347) het hierdie gedagte verder ontwikkel en oordeel dat nie óns 'n teks uitlê nie, maar omgekeerd, die teks lê ons uit en bring ons tot selfverstaan. ${ }^{9}$ Hierdie hermeneutiek wil dus geensins 'n vooronderstelling wat

\footnotetext{
${ }^{7}$ Alhoewel Karl Barth alreeds in sy Göttingen Dogmatiek die aposteriori in die teologie toegee, het hy dit tog nie tot die werklike konsekwensie deurgevoer nie. Die klassieke credo ut intelligam draai hy inderwaarheid om en gevolglik ook esse en significare. Kyk hiervoor my artikel oor die huwelik by Luther in HTS 63(2), 445-461. Dit is juis hierdie aspek wat Barr en Veldsman ook aanvoel (kyk bo), dog nie so weergee nie.

${ }^{8}$ Om ' $n$ verstaan en toepassing van o a sodanige prinsipe in die Afrikaanse teologie na te gaan, kyk Loader (1979:1-25).

${ }^{9}$ Vir 'n goeie eksposisie van Ebeling se hermeneutiek in Afrikaans, vergelyk Pieterse, $\mathrm{H} \mathrm{J} \mathrm{C}$ (1979), Skrifverstaan en Prediking. Pretoria: NGK Boekhandel.
} 
alle verstaan bepaal, verdiskonteer (verhandel/wissel) nie. Bonhoeffer stel dit elders ook baie duidelik:

Theological exposition takes the Bible as the book of the church and interprets it as such. This is its presupposition and this presupposition constitutes its method: its method is a continual returning from the text (as determined by all the methods of philological and historical search) to this presupposition. That is the objectivity [Sachlichkeit] in the method of theological exposition.

(Bonhoeffer 2004:22-23)

Dit beteken dus dat 'n teks altyd uit die omvattende kompleks van spreker, teks en leser tesame met die onderskeie kontekste daarvan, verstaan moet word. Gadamer het in hierdie opsig 'n groot bydrae gelewer deur te stel dat daar met 'n bepaalde verwagting na die teks toe gegaan word as sou dit 'n belangrike boodskap inhou. Die universele boodskap van die Skrif oorbrug die tyd-ruimtelike afstand tussen die teks en die leser. In hierdie spel wat hom afspeel, hierdie vra en gevra wórd, word vooroordele blootgelê en kom 'n nuwe verstaan tot stand wanneer die horisonne versmelt (Gadamer 2004:305, 389).

Die implikasie vir die Skrif is dus duidelik. Daar is geen eenduidige of finale lees van die teks moontlik nie. Die simbool kan die referent nooit volstrek weergee nie. Die Christelike geloof word dus aan ' $n$ interne pluraliteit geken. Die betekenis word nooit uitgeput nie en daar is altyd 'n surplus of res van betekenis wat nie tot uitdrukking gebring word nie (Ricoeur, ook Derrida). Boonop is daar ook 'n grens aan verstaan. Die integriteit van teks met sy tradisie moet gerespekteer word en daarin setel 'n bepaalde outoriteit. Ons kan dus saamgaan met die siening van Tom Wright (2005:116) dat alhoewel martelare vir hierdie Skrif gesterf het, die Bybelse outoriteit binne die koninkryk van God verstaan moet word, wat van die kosmiese af, verby die politieke, tot by die persoonlike sfeer strek. Gesag is 'n ontmoetingsbegrip en die auctoritas van die Skrif, dus ewe-eens ontsag.

Hierdie verhouding tussen spreker, teks en leser is natuurlik ook glad nie so vanselfsprekend as wat ons dalk mag vermoed nie! Ricoeur (1990:5287) wil die hermeneutiese proses veral 'n semantiese aangeleentheid maak en vra, op grond van sy analise van Aristoteles se werke, na die psigologiese prosesse in die verstaan van die teks self wat jou uiteindelik uitbring by die drievoudige mimesis van oriëntasie (prefigurasie, konfigurasie en refigurasie). Verstaan word in terme van die teks (outonome aspek), die bepaalde genre (eksterne aspek) en die referensie van die teks (transendente aspek) as generatiewe poësie gekonstitueer. Die komposisie, genre en styl van 'n diskoers word dus in berekening gebring om die interne referent aan te dui. Gods transendensie as interne referent is dus nie buite die geloofsdiskoers 
om nie (Brabant 2008:185). Openbaring word gevolglik nie geverifieer (of gefalsifieer) nie, maar gemanifesteer. Ricoeur (1994:102) stel dit lapidêr: "In turn, this poetic function conceals a dimension of revelation where revelation is to be understood in a nonreligious, nontheistic, and nonbiblical sense of the word - but one capable of entering into resonance with one or the other of the aspects of biblical revelation." Die wêreld waarna die teks verwys, is nie die wêreld agter die teks nie, maar 'n geprojekteerde wêreld vóór die teks in terme van die belydenis van die subjek. Openbaring is dus vir Ricoeur wat deur die teks teweeggebring word, sonder enige sweem van heteronomie. Verbeelding word nou die vermoë om die werklikheid te refigureer en moontlikhede te sien wat nog nie bestaan nie. In die sin steun die verbeelding op die deskriptiewe verwysing van die werklikheid om 'n verdere verwysing wat meer as suiwer beskrywing tot stand te bring (Brabant 2008:189).

Hierdie ónvanselfsprekendheid impliseer ook 'n bepaalde vervreemding. 'n Metafoor koppel immers altyd ongelyksoortige teenoorgesteldes deur die dubbele referensie van die "is" én die "is nie", in die vergelyking op te neem (kyk ook McFague 1982:65). Die werklikheid word in die lig hiervan herinterpreteer en nuwe moontlikhede word ontsluit. Die metafoor skep en herskep die werklikheid in aansluiting by wat in die werklikheid gevind en ontdek word. Dit is juis hierdie kreatiewe dialektiek wat Moltmann byvoorbeeld wil aanwend in sy hermeneutiese ontwerp: "It is only in the foreign land that we understand what home is. It is only in the face of death that we sense the uniqueness of life" (Moltmann 2000:171). Hierdie dialektiek moet ook as 'n sinekdogee opgeneem word waar die onderdeel die geheel veronderstel en die teenoorgesteldes dus nie net mekaar se teendeel is nie, maar volgens Moltmann (2000:178) juis mekaar se identiteit is.

In hierdie verband kan ons selfs van die Bybel in terme van Gestalt praat (Sauter \& Barton 2000:80). So word die Bybelteks 'n verhalende, koherente entiteit in terme van die gelowiges se ontvangs daarvan. Die resepsie word onontbeerlik om die stem van God te hoor. Calvyn (Inst I.7.4) formuleer dit korrek wanneer hy stel:

Want soos God alleen in sy Woord 'n bekwame Getuie vir Homself is, sal die Woord geen geloofwaardigheid in die hart van die mens vind voordat dit deur innerlike getuienis van die Gees beseël word nie. Gevolglik moet dieselfde Gees wat deur die mond van die profete gespreek het, noodwendig ons hart binnedring om ons te oortuig dat Hy dit wat God verbied het, getrou aan ons oorgedra het.

Hierdie proses omvat menswees in totaliteit - kognitief en emotief. Dit is natuurlik in hierdie opsig dat 'n aantal Yale teoloë die belang van kultuur en taal so voorop gestel het. Byna soos die Kantiaanse apriori vorm en slyp hierdie kommunale raamwerk die betrokkenes daarin (Lindbeck 1984:33). 
Derhalwe het die Faith and Order kommissie van Montreal (1963) dit reg as hy die onderskeid tussen Skrif en Tradisie relativeer. Dit tref die bruikbare onderskeid tussen Tradisie met 'n hoofletter en tradisie met ' $n$ kleinletter; eersgenoemde is die evangelie self en laasgenoemde is die kerke se onderskeie (en verskillende!) oordrag daarvan (World Council of Churches 1980:2-19). Tradisie word gevolglik as 'n proses verstaan:

\begin{abstract}
Our starting-point is that we are all living in a tradition which goes back to our Lord and has it roots in the Old Testament, and are all indebted to that tradition inasmuch as we have received the revealed truth, the Gospel, through its being transmitted from one generation to another. Thus we can say that we exist as Christians by the Tradition of the Gospel (the paradosis of the kerygma) testified in Scripture, transmitted in and by the Church through the power of the Holy Spirit. Tradition taken in this sense is actualized in the preaching of the Word, in the administration of sacraments and worship, in Christian teaching and theology, and in mission and witness to Christ by the lives of the members of the Church.
\end{abstract}

(World Council of Churches 1980:20)

Hiermee is die tradisionele Rooms-Katolieke standpunt van die Skrif én die tradisie as kenbron teenoor die Protestante se sola scriptura in 'n nuwe raam geplaas. Tydens hierdie byeenkoms het Ernst Käsemann (1963) ook sy bekende voordrag gehou oor die diversiteit van ekklesiologieë in die Nuwe Testament. Van toe af was dit net nie meer in die teologie moontlik om die bepaalde lidwoord, "die", te gebruik by sake soos Bybelse boodskap, tradisie, verstaan ensovoorts nie. Die outoriteit van die Bybel is gevolglik toe ook by ' $\mathrm{n}$ latere byeenkoms van hierdie Kommissie in Leuven (1971) dinamies as 'n relasionele aangeleentheid in terme van ' $n$ transendente ervaring geïnterpreteer (World Council of Churches 1980:6) - 'n spoor wat die GKNRapport (1981) toe later gevolg het. Dit het van inspirasie - en kanonisering nie 'n uitgangspunt gemaak nie, maar wel 'n konklusie. 'n Geloofsuitspraak word dus terugskouend oor die Skrif gemaak wat die meervoud van woorde in die enkelvoud van die Woord laat opgaan en die Skrif dus 'n "eksentriese" middelpunt laat kry. Juis daarom is ook die geloofsgemeenskap nou "ektopies", haar plek is in die kreatiewe en kommunikatiewe God van die Evangelie (Webster 2003:47). Soos die Skrif, is die tradisie dan in diens van hierdie Woord, sowel wat die bewaring as die deurgee daarvan betref. En daarom praat ons van die Heilige Skrif.

Aangesien die oorsprong van geloof alleen maar God kan wees en sowel die Skrif as die tradisie net daarvan kan getuig, raak die teenoormekaarstelling van Skrif en tradisie inderdaad relatief (Küng 1991:56). Die 
Skrif behou nietemin sy normatiewe waarde. Sauter is derhalwe ook baie duidelik daaroor dat mens nie "behind the Bible" durf gaan nie, wat ek interpreteer as dat die Bybelteks nie verbygegaan mag word nie (Sauter \& Barton 2000:9-10). Alle Christelike diskoers moet aan die gebeure van God wat in Jesus Christus tot spreke kom, geyk word. Die Bybel bly dus die uitgangspunt in die werklikheid waar die verwysing na die transendente begin. Dit is die konkrete en tasbare simbool wat na God reik. Hierdie onderlinge akkoord van die kerk is ook al manier hoe daar verby die kritiek van byvoorbeeld Deist (1979:57-59) gekom kan word wat baie stellig daaroor is dat die Woord van God nooit 'n konstante referent in die geskiedenis gehad het nie en daarom altyd kontingent is.

Kortom, vir die Christelike teologie is dit dus belangrik om te begin waar sowel die Skrif as die tradisie begin, naamlik by God self wat in sy Seun, Jesus Christus, tot spreke kom. Ontologies is dit ononderhandelbaar, noëties egter onmoontlik. Hierdie boodskap is intrinsiek in 'n Bybelse diskoers met sy meta-narratief van die lewe, dood en opstanding van Jesus Christus verweef. En hierdie oortuiging, glo ons, kom van God af (I Kor 12:3). En omdat die mens altyd ingebed is in 'n simboliese universum, is die "deurvertaling" (Berkhof 2007:93, 95) van die Bybelse kerugma die verhaal van God wat my eksistensieel in God se verbond inbind. Die verskillende koördinate van die verhaal konvergeer wanneer dit my as individu aanspreek en sluiting laat plaasvind. Paul Fiddes verwys byvoorbeeld in hierdie opsig na The Tempest waar Shakespeare teen alle konvensie en verwagting in, sy hoofkarakter, Prospero, in die slottoneel met die teatergangers laat praat en hulle applous versoek ter ondersteuning van sy terugtog na die prinsdomme van Napels en Milaan (Sauter \& Barton 2000:29). Dalk is dit wat ook gebeur wanneer Jesus "wegdraai" van sy dissipels af in die bovertrek in Jerusalem en met ons vandag praat: "Gelukkig is dié wat nie gesien het nie en tog glo" (Joh 20:29).

Samevattend kan ons na Nürnberger (2004:27-39) se weergawe van die hermeneutiek verwys hoe die Skrif nou gelees kan word: van agter, van bo, van voor, van binne of van onder af - elk met sy unieke aanbod. Om die Bybel van agter te lees het die aanname dat die openbaring voor die teks gepeil kan word; om die Bybel van voor te lees, wend die Skrif soos 'n spieël aan om die self daarin terug te vind; ander wil weer leerstellings as die ewige waarheid bo die Bybel sien; en nog ander isoleer die Bybeltekste van hulle onderskeie historiese beddings en hanteer die Bybel monolities op sigself. Self verkies Nürnberger ' $n$ "van onder" af benadering omdat dit God se heilsbedoeling met die mens in die vorm van bepaalde onderliggende trajekte in die tekste veronderstel. 
Ons moet altyd ook op 'n antroposentriese reduksie van die heil bedag wees. Dit is reeds gesê dat die kontinentale teologie anders oor openbaring oordeel as die Anglo-Saksiese teologie. Heelwaarskynlik het dit direk met Karl Barth se Nein teen enige vorm natuurlike teologie te doen. Openbaring van die Gans Andere is vir hom senkrecht von oben en God praat met ons op geen ander manier en met geen ander woord as Jesus Christus nie (kyk bv die eerste artikel van die Barmen Verklaring). Reeds in sy Göttingen Dogmatiek het Barth (1991:14-15) die Selfbekendmakende Woord van God drievoudig geïnterpreteer as inkarnasie, Skrif en verkondiging. Die Woord van God is dus vir hom drie in een en een in drie wat nog vermeng nog geskei kan word en dit spel alleen maar Jesus Christus uit. Dogmatiek is vir hom dus konsekwent soteriologies bepaald. Barr (1994:190) kritiseer Barth ook ronduit: "The biblical evidence does point towards natural theology as anterior knowledge, and Barth in rejecting this was simply wrong. He was forcing the biblical material into his own dogmatic mould." Min teoloë het egter meer moeite gedoen om hierdie insig van Barth te herinterpreteer en binne 'n groter horison te plaas as juis die Skotse teoloog, Thomas Torrance. Ek wil hom derhalwe as eksponent aanwend om te illustreer dat die gelowige se betrokkenheid met die natuurwetenskappe, juis ook kan lei tot 'n stratifikasie van teologiese insigte wat 'n dekonstruksie van die begrip openbaring tot gevolg het. 'n Bydrae wat McGrath (2002:237) Torrance ook geredelik toegee.

Torrance (2001:87-95) stel herhaaldelik in sy boeke dat die byltjie wat Barth met 'n natuurlike teologie te slyp gehad het, inderwaarheid teen 'n deïsme gemik was wat die natuur 'n selfstandige rol, los van die openbaring van God, toegesê het. Natuurlike teologie behoort as die kleiner sirkel binne die groter sirkel van die openbaring van God verstaan te word. Vir Torrance is dit derhalwe belangrik om die skeppingsleer en die inkarnasie op so 'n manier bymekaar uit te bring dat die onderliggende dualisme oorkom kan word. Hiervoor laat hy hom bedien met die insigte van veral Polanyi om by 'n gestratifiseerde verstaan van die werklikheid uit te kom: die eerste vlak van toevallige kennis; die tweede vlak van wetenskaplike teorie; en laastens die verfynde vlak van abstraksie met 'n maksimum moontlike onafhanklikheid (Torrance 1996:84). Toegepas op die Christelike geloof, is die drie vlakke dan basiese geloofservaring, die tweede vlak die van teologie en die derde die van ontiese besinning. In terme van God se Selfopenbaring, kom hy dan (binne die openbaring) tot die volgende resultaat van toenemende begrip: ${ }^{10}$ ervaring van God $\rightarrow$ ekonomiese Triniteit $\rightarrow$ immanente Triniteit (Torrance 1996:107).

\footnotetext{
${ }^{10}$ Dit val op dat hedendaagse teoloë graag van 'n tipe rimpel-beeld gebruik maak om die Skrif se integriteit te probeer aantoon. Brueggemann (2003:49) doen dit aan die hand van die primêre narratief wat algaande uitdy. Wright (2005:121) doen dit weer aan die hand van die gelaagdheid van sentrale Bybelse temas. Nürnberger (2004:38) identifiseer weer ses Bybelse trajekte wat hom 'n "below-the-text reading" laat veroorloof.
} 
McGrath (2006:194-203) sluit hierby aan wanneer hy met sy "wetenskaplike teologie" (scientific theology) 'n krities-realistiese werklikheidsverstaan daarstel waar die intra-sistemiese werklikheid van die teologie toenemend aan die ekstra-sistemiese werklikheid van die natuurwetenskappe korrespondeer. Soos 'n spiraaltrap lei hierdie "iteratiewe prosedure" van vergelyking en evaluasie na 'n bepaalde punt van ekwilibrium wanneer bepaalde resultate voorlopig uitkristalliseer. Die kerk se verstaan van die Triniteit illustreer dit weereens. McGrath (2006:202) konkludeer: "But where Barth seems to treat revelation in somewhat abstract, unhistorical terms, my approach allows me to begin from the historical actuality of revelation, before returning to offer a theoretical justification and elaboration of the idea." Die verskillende iterasies sal dan vir hom soos volg daar uitsien: aktualiteit van die kerk $\rightarrow$ Christologie $\rightarrow$ Triniteit. Soos vir Schleiermacher, is die Triniteit dan vir hom nie die vertrekpunt van die teologie nie, maar 'n eindpunt, 'n verposing van die geloofsgemeenskap se teologiese kontemplasie oor God ${ }^{11}$. Dit klop ook ongeveer wat Ricoeur met sy hermeneutiese sirkel sou bedoel: mens moet glo om te dink en dink om te glo (Brabant 2008:182).

Alhoewel bogenoemde eksposisie seer sekerlik ontoereikend is en heelwat vrae oproep, is dit ter wille van die skopus van hierdie artikel nodig om hiermee te volstaan. Die punt wat oorgebring moet word, is dat omdat natuur binne die groter raam van openbaring verstaan word, ons inderdaad in dialoog met nie-teologiese wetenskappe, aposteriories in ons verstaan van die werklikheid kan baat. Die klassieke debat oor die "twee boeke van God" (vgl Artikel 2 van die NGB) blyk tegelyk uitgediend en aktueel te wees. Dit gaan nie om twee "bronne" nie, maar om 'n koherente geheel, 'n Gestalt waarin die gelowige tot verhaal kom. En hiervoor is ook die rede noodsaaklik, al vra Tom Wright (2005:119) ewe tong-in-die-kies, "whose rationality?" Dit vorm 'n noodsaaklike middel om juis God se stem te hoor soos deur die Skrif en tradisie geresoneer word en nie deur die weerklank van ons eie stemme nie.

\footnotetext{
${ }^{11}$ Hierdie iteratiewe prosedure tussen kerklike nadenke en nie-teologiese wetenskappe (natuur-, sosiale en gedragswetenskappe) kan ook geïllustreer word aan die huidige teologiese debat oor homoseksualiteit. Vir eeue is die verskynsel deur die kerk gewoon as sonde afgemaak en is betrokkenes geostraseer. Die verskillende wetenskappe het ons egter gelei om sowel die genetiese predisposisie as die sosiale en psigologiese invloede te verreken. Uitgedruk in terme van bogenoemde stygende spiraal, sou dit moontlik wees om hierdie insig soos volg voor te stel: homo sapiens $\rightarrow$ imago Dei $\rightarrow$ broer/suster in Christus. Kyk hiervoor Buitendag (2007). Kyk weer Rogers (2006) vir ' $n$ insiggewende weergawe van die wisselwerking van teologie met sosiale en politieke faktore in die VSA.
} 


\section{SAMEVATTENDE GEVOLGTREKKINGS}

- Dogmenhistories is dit duidelik dat die Protestantse skolastiek die sola scriptura oorspan het. Dit is losgemaak van die regverdigingsleer wat alleen deur Christus kan geskied en deur die ander sola-uitsprake gekwalifiseer moet word. Inderdaad word die indruk dan geskep dat die Bybel by die Protestante, die plek van die kerk by die Rooms-Katolieke Kerk ingeneem het. Dit voer ook tot die futiele vraag wat eerste is, die kerk of die Bybel? Ons moet fundamenteel tussen die Skrif, die Woord en die openbaring onderskei. Dit is prinsipieel korrek om by die openbaring te begin as synde die gratia praeveniens van God, maar is noëties gewoon nie moontlik nie. Openbaring kan ook nie as die loodregte inbreuk van bo gesien word wat in die Skrif gestol het nie. Die Bybel is nie 'n stuk sediment van die openbaring waarop greep uitgeoefen kan word nie. Openbaring kan nooit verobjektiveer word nie. Openbaring is immers nie iets van God nie, maar God sélf wat genadiglik na sy skepping toe uitreik. Dit is inderdaad ook ' $n$ vraag of die woord openbaring enigsins nog die debat dien. Die verskillende modelle van openbaring dui daarop dat die teologie in elk geval eerder met 'n hibriede verstaan van openbaring sal moet klaarkom.

Waarskynlik is die coram Deo of "God met ons", gunstige alternatiewe om in hierdie opsig te oorweeg; nie net die geskiedenis nie, maar ook die natuur word sodoende verreken.

- God kom tot spreke in Jesus Christus, of dalk beter geformuleer, "Jesus Christus ist der Sprecher der Sprache Gottes in der Geschichte" (Ott \& Otte 1999:254). Dit beteken minstens die volgende vyf perspektiewe: dat God in die menslike geskiedenis inkom en met die mens in gesprek tree; God se openbaring is nie onhistories, metafisies of orakelagtig nie; God het op 'n baie spesifieke tyd en plek God self geopenbaar en is soos elkeen van ons in 'n konkrete situasie te interpreteer; omdat Jesus die Spreker van Gód is, het die uitwerking universele draagwydte en oorstyg dit ruimte en tyd; en laastens, God praat met die mens in 'n menslike taal en bedoel dus om gehoor en verstaan te word. As Christengelowiges kan ons nie by hierdie saak verbygaan nie en durf ons ons nie veroorloof om "agter die skerms" insig te bekom nie. Ons kan alleen oor God in sy ekonomie van heil praat. Dit is sowel eksegeties as hermeneuties onhoudbaar om die Skrif so uit te lê dat dit 'n immanente prinsipe kommunikeer. 'n Ontologie van die Skrif bestaan eenvoudig nie (contra Topping 2007:213). Daarvoor is die diversiteit van getuienis net te 
vanselfsprekend. Die gelowige kan egter vanuit persoonlike oortuiging en gevorm deur sy of haar simboliese universum, in die Bybel wel onderskei tussen middelpunt en omtrek, pieke en vlaktes, sonder om formeel 'n kanon in die kanon te probeer daarstel. Daarvoor is ons insigte immers te subjektief en voorlopig. Bybelse begronding beteken dus ook nie om Bybelversies te siteer nie. Nie alleen doen dit onreg aan die integriteit van die teks in sy geheel nie, maar verdoesel dit 'n vooronderstelling waaruit gelees word. Bybelse begronding is om God se spreke in Jesus Christus soos getuig in die Skrif en geïnterpreteer deur die geloofsgemeenskap, te laat hoor. Die Bybelse begronding vind plaas wanneer die integriteit van die Skrif erken word, 'n gees van afwagting en oortuiging bestaan en God in die tweede persoon enkelvoud, as die "U" (Buber), gehoor word. Scriptura sacra sui interpres is dus geen eksegetiese tegniek nie, maar die oortuiging dat God in Jesus Christus tot spreke kom. Te midde van 'n ná moderne pluralisme, is hierdie die "meta-narratief" waaraan die Christelike kerk ononderhandelbaar bly vaskleef.

- Geloof is daarom die sine qua non om die Skrif in hierdie lig te lees en te verstaan. Regeneratio is om deur Gees van God aangeraak te word en te erken dat Jesus die Christus is. Konfrontasie hiermee disoriënteer mens, maar heroriënteer ook. Daarom sal die appèl tot bekering en versoening in Skrifverstaan ook altyd gehoor en nagestreef moet word. Gadamer stel dit duidelik dat die leser altyd met 'n bepaalde verwagting na die teks toe gaan en kan Tillich hierdie verwagting ook in terme van eksistensieel-kontekstuele vrae interpreteer wat aan Bybelse antwoorde korreleer. Webster is waarskynlik reg wanneer hy die uitwerking van God se openbaring in die heiligmaking en inspirasie sien. Hierdie geloofsverhouding as uitgangspunt vra uiteraard dat die Adam in ons gekruisig moet word. Die evangelie druis teen alle natuur in en vanselfsprekende antwoorde is juis onevangeliese antwoorde! Sauter (in Sauter \& Barton 2000:16) stel met oortuiging dat sola scriptura begin met spanning en konflik dit spreek so anders as wat menslik gesproke, dikwels graag gehoor wil word. Smit (2006:51) gee hierdie aspek van Calvyn se Skrifbeskouing treffend mee wanneer hy stel dat wanneer die Woord van God deur die Bybel wel tot spreke kom, dit die lesers "verras, oorweldig, uitdaag, ontstel, konfronteer, verbaas". Dit is die Gees wat by die letter kom, die evangelie by die wet, die belofte op die vervulling. 
Die gesag van die Skrif is dus 'n ontmoetingsbegrip wat 'n Jeremia kon laat sê: "U was te sterk vir my, U het gewen" (Jer 20:7).

- Maar dis nie net 'n saak tussen my en God nie. Die ek-U relasie kort ook die derde term van hy/dit (Ricoeur 1980:89-90). Die mens is altyd ingebed binne 'n kultuur-linguistiese nis wat alle verstaan bepaal of minstens beïnvloed. Gister se openbaring is vandag se tradisie en dit weer vorm die basis vir môre se insigte. Openbaring moet vasgelê word, maar tegelyk ook "deurvertaal" (Berkhof) of "weitergesagt" (Gadamer) word. Sonder vertolking verstar die geloof in proposisies en sonder vaslegging vervloei dit in persoonlike opinies. Die Heilige Skrif is dus die vaslegging van die getuienis van God se betrokkenheid in die geskiedenis. Dit is daarom altyd ook geïnterpreteerde Skrif. Dit is nie die openbaring self nie - net die getuienis daarvan. Karl Barth het waarskynlik te ver gegaan om die Woord drievoudig te verstaan: slegs die geïnkarneerde Woord is die openbaring van God - die ander is getuienis (kyk ook Barr 1994:195-196). In hierdie opsig is tradisie ook van dieselfde aard as die Skrif. Die Skrif interpreteer egter alle ervaring en moet derhalwe ook die tradisie yk. Dit is dus die ooreengekome maatstaf wat deur die geloofsgemeenskap erken word. Erken ja, want daar kan nie werklik uit die sirkelredenasie ontsnap word dat die kerk die kanon bepaal en die kanon weer op sy beurt die kerk konstitueer nie. Tog wil die geloof ook hê dat die Skrif as norm herken word, dat die Skrif die resultaat van 'n lang teologiese - én ander ${ }^{12}$ - oorwegings was. Daarom is die Skrifprinsipe eerder 'n kerkprinsipe (Barr 1994:197). Dit word vandag wyd aanvaar dat die narratief ("storie") sowel wat die Skrif as die geïnkorporeerde geskiedenis betref, die mees toepaslike genre is om die boodskap in Jesus by ons te laat tuiskom (Frei 1974). Dit skep 'n interaktiewe Gestalt met die geloofsgemeenskap wat die individu tot 'n eksistensiële beslissing bring ("closure") en doen daarom reg aan die sogenaamde resepsie van die boodskap.

- Openbaring is 'n abduktiewe aangeleentheid. Die wisselwerking tussen God, mens en skepping vind in Jesus Christus 'n konkreet-historiese gestalte. Dialoog is daarom ewe belangrik met die wêreld as met die

\footnotetext{
${ }^{12}$ Kyk hiervoor Dungan, D L 2006. Constantine's Bible: Politics and the making of the New Testament. Philadelphia, PA: Fortress. Ferdinand Deist (1979:56) verwys met instemming ook na 'n aanhaling van $\mathrm{G} E$ Lessing wat stel: "Ich hatte ... behaupten zu dürfen geglaubt, dass ... die christliche Religion ... sich weder auf die ganze Bibel, noch auf die Bibel einzig und allein gründe."
} 
verskillende wetenskappe wat eweneens trag om die werklikheid te begryp. Dit is die teologie se beskeie oortuiging dat hy nie net by hierdie dialoog kan baat nie, maar selfs ook 'n bydrae kan maak. Vergelyk byvoorbeeld die aanbod wat Van Huyssteen (2006) tot die paleoantropologie maak. Waar die Skrif verstaan word in terme van Jesus Christus as die spreke van God se taal in die geskiedenis (oftewel skepping), raak hierdie gesprek soveel te meer onontbeerlik. Dit gee ons ook insig op sake veral soos die natuur, die tyd, die kwaad, die goeie en die mens. Omdat die Skrif nie ontologies as bron verstaan kan word nie, maar as getuienis daarvan, is die felle debat met die RKK oor die tradisie ook grootliks gerelativeer. Die kerk kan ook nie deur ander getuienis onaangeraak wees nie. Die verskil tussen voorlopig en volkome (kyk weer Art 7 van die NGB) is weliswaar gradueel, dog nie prinsipieel nie. Maar hiermee word die terrein van die eskatologie betree.

Dalk het Placher (1994:127-128) tog iets beet wanneer hy die volgende oor Skrifverstaan konkludeer:

The sort of theology here described has neither a doctrine of scripture nor a set of philosophical prolegomena that would function as some sort of foundation to the whole. It has a set of doctrines and practices, among which there are some beliefs about the function of scripture in the life of the Christian community... Perhaps we should stand, from the start, with the crucified Jesus and the vulnerable God he makes known to us.

(Placher 1994:127-128)

\section{Literatuurverwysings}

Barr, J 1977. The Bible in the modern world. London: SCM.

Barr, J 1994. Biblical faith and natural theology. Oxford: Clarendon.

Barth, K 1961. Church dogmatics: A selection with introduction by Helmut Gollwitzer, tr by G W Bromiley. Edinburgh: T\&T Clark.

Barth, K 1991. The Göttingen dogmatics: Instruction in the Christian religion, Vol I, edited by $\mathrm{H}$ Reiffen, and tr by G W Bromiley, Grand Rapids, MI: Eerdmans.

Berkhof, H 1977. The doctrine of the Holy Spirit. Atlanta, GA: John Knox.

Berkhof, H 2007. Christelijk Geloof, $9^{e}$ editie. Kampen: Kok.

Bonhoeffer, D 2004. Creation and fall. Minneapolis, MN: Fortress.

Bonhoeffer, D 1954. Life together. San Francisco, CA: HarperCollins.

Brabant, C 2008. Geloof, waarheid en referentie. Tijdschrift voor Theologie 48, 182198. 
Brueggemann, W 2003. The Bible makes sense, 2nd ed. Cincinnati, OH: St Anthony Messenger Press.

Buitendag, J 2007. "Genes я us" - of juis nie? Slagoffer of eie keuse?, in C Vos, \& D Human, Liefde is die grootste: Oor erotiek en seksualiteit, 417-434. Pretoria:

Protea Boekhuis.

Calvyn, J 1992. Institusie van die Christelike Godsdiens, vertaal deur H W Simpson,

Potchefstroom: CJBF. (Logos Library System ed.).

Cobb, J B 1994. Lay theology. St Louis, MA: Chalice.

Collins, J J 2005. The Bible after Babel: Historical criticism in a postmodern age.

Grand Rapids, MI: William B Eerdmans.

Deist, F E 1979. The Bible - The word of God, in W S Vorster (ed), Scripture and the use of Scripture, 41-74. Pretoria: UNISA.

Dulles, A 2004. Models of revelation. New York: Maryknoll.

Ebeling, G 1960. Wort und Glaube, Vol I. Tübingen: J C B Mohr (Paul Siebeck).

Ebeling, G 1977. Martin Luther: Einführung in sein Denken, 4th ed, Vols. Tübingen: J C B Mohr (Paul Siebeck). (Uni-Taschenbücher 1090.)

Frei, H 1974. The eclipse of Biblical narrative. New Haven, CT: Yale University Press.

Fretheim, T E, \& Froelich, K 1998. The Bible as word of God: In a postmodern age. Minneapolis, MN: Fortress.

Gadamer, H-G 2004. Truth and method, $2^{\text {nd }}$ rev ed, tr by J Weinsheimer, \& D G Marshall. London: Continuum.

GKN-Rapport 1981. God met ons: Over de aard van het Schriftgezag. Utrecht: TijlLibertas. (Speciaal Kerkinformatie, 113.)

Jenson, R W 1991. Systematic theology: The works of God, Vol II. Oxford: Oxford University Press.

Käsemann, E 1963. Unity and diversity in New Testament ecclesiology. NT 6(4), 290297.

Küng, H 1991. Theology for the third millennium. London: HarperCollins.

Lindbeck, G A 1984. The nature of doctrine: Religion and theology in a postliberal age. Philadelphia, PA: Westminster.

Loader, J A 1979. The use of the Bible in conventional South African theology, in W S Vorster (ed), Scripture and the use of Scripture, 1-25. Pretoria: UNISA.

Luther, M 1999. Lectures on Genesis: Chapters 15-20, Vol 3, edited by Pelikan, J J Oswald, H C \& Lehmann, H T and tr by G V Schick. Saint Louis, MO: Concordia.

Luther, M 1983. Der Große und der Kleine Katechismus. Göttingen: Vandenhoeck \& Ruprecht.

Luther, M 1999. Devotional writings, Vol 42, edited by Pelikan, J J, Oswald, H C \& Lehmann, H T. Philadelphia, PA: Fortress.

McFague, S 1982. Metaphorical theology: Models of God in religious language. Philadelphia, PA: Fortress.

McGrath, A E 2002. A scientific theology: Reality, Vol II. London: T\&T Clark. 
McGrath, A E 2003. A scientific theology: Theory, Vol III. Nature. Grand Rapids, MI: William B Eerdmans.

McGrath, A E 2006. The order of things: Explorations in scientific theology. Oxford: Blackwell.

Mollet, T, Grundling, E, \& Van Heerden, E 2004. Die omstrede God: Bestaan God of nie? Die groot debat op www.litnet.co.za. Stellenbosch: Rapid Access.

Moltmann, J 2000. Experiences in theology: Ways and forms of Christian theology, tr by M Kohl. Minneapolis, MN: Fortress.

Nürnberger, K 2004. Biblical theology in outline. Pietermaritzburg: Cluster.

Nürnberger, K 2005. Martin Luther's message for us today. Pietermaritzburg: Cluster. Ott, H, \& Otte, K 1999. Die Antwort des Glaubens: Systematische Theologie in 50 Artikeln. Stuttgart: Kohlhammer. (3. überarbeiteten und erweiterten Auflage ed.)

Pannenberg, W 1975. Faith \& reality. London: Search Press.

Pannenberg, W 1979. Grundfragen Systematischen Theologie. Göttingen: Vandenhoeck \& Ruprecht.

Placher, W C 1994. Narratives of a vulnerable God: Christ, theology, and Scripture. Louisville, KY: Westminster John Knox.

Ricoeur, P 1980. Essays on Biblical interpretation, edited by L S Mudge. Philadelphia, PA: Fortress.

Ricoeur, P 1990. Time and narrative, Vol I, tr by K McLaughlin, \& D Pellauer. Chicago, IL: University of Chicago Press.

Rogers, J 2006. Jesus, the Bible, and homosexuality. Louisville, KY: Westminster John Knox.

Sauter, G \& Barton, J 2000. Revelation and story: Narrative theology and the centrality of story. Aldershot: Ashgate.

Schnabel, E J 2008. Scripture, in Alexander, D \& Rosner, B (eds), New dictionary of Biblical theology, 34-43. Leicester: Inter-Varsity Press.

Schillebeeckx, E 1966. Openbaring en theologie, Vol I. Bilthoven: H Nelissen.

Schüssler Fiorenza, E 1984. Bread not stone: The challenge of feminist Biblical interpretation. Boston, MA: Beacon.

Smit, D 2006. Neem, lees!: Hoe ons die Bybel hoor en verstaan. Wellington: Lux Verbi Bm.

Smith, J K 2007. Who's afraid of postmodernism?: Taking Derrida, Lyotard, and Foucault to church. Grand Rapids, MI: Baker Academic.

Steinmetz, D C 2002. Luther in context, 2nd ed. Grand Rapids, MI: Baker Academic.

Theissen, G 2007. The Bible and contemporary culture, tr by D E Green.

Minneapolis, MA: Fortress.

Tillich, P 1964. Systematic theology, Vol I. Digswell Place: James Nisbet.

Topping, R R 2007. Revelation, Scripture and church. Burlington: Ashgate.

Torrance, T F 1997. God and rationality. Edinburgh: T\&T Clark.

Torrance, T F 1996. The Christian doctrine of God: One Being and Three Persons. Edinburgh: T\&T Clark.

Torrance, T F 2001. The ground and grammar of theology. Edinburgh: T\&T Clark. 


\section{"God met ons": Gelowig nagedink oor die Skrif}

Van Huyssteen, J W 2006. Alone in the world?: Human uniqueness in science and theology. Grand Rapids, MI: William B Eerdmans.

Van Huyssteen, J W, \& Du Toit, B 1982. Geloof en Skrifgesag: 'n Analise van die Skrifgesagprobleem na aanleiding van die rapport "God met ons". Pretoria: NG Kerkboekhandel.

Veldsman, D P 2007. Karl Barth's epistemology: A critical appraisal. HTS 63(4), 1337-1345.

Vorster, W S (ed) 1979. Scripture and the use of Scripture. Pretoria: UNISA.

Weber, O 1972. Grundlagen der Dogmatik, 4th ed, Vol I. Neukirchen-Vluyn: Neukirchener Verlag.

Webster, J 2003. Holy Scripture: A dogmatic sketch. Cambridge: Cambridge University Press.

Westermann, C 1978. Theologie des Alten Testaments in Grundzügen. Göttingen: Vandenhoeck \& Ruprecht.

World Council of Churches. 1980. The Bible: Its authority and interpretation in the ecumenical movement, edited by E Flesseman-van Leer. (Vol Faith and Order Paper No 99). Geneva: WCC.

Wright, N T 2005. The Last Word: Scripture and the authority of God-getting beyond the Bible and wars. San Francisco, CA: HarperCollins. 